\title{
Control of vole populations in young pine plantations in northeast China
}

\author{
by Thomas P. Sullivan ${ }^{1}$, Jin Zhen-hao², Li Heli, and Wang Shou-cai
}

\begin{abstract}
This paper reports influences of rodent pests on forest regeneration in northeastern China and methods, other than toxicants, to reduce feeding damage to trees by the red-backed vole (Clethrionomys rufocanus). Studies were conducted in 7- to 8-year-old plantations of Scotch pine (Pinus sylvestris) at NanGou Forest Farm, 15 km southeast of Langxiang, Heilongjiang Province. Stem analysis indicated that radial growth was reduced $27.5 \%$ and height growth $30.5 \%$ in damaged (sub-lethal) versus undamaged trees. Synthetic predator odour repellents based on weasel (Mustela erminea) anal-gland secretion significantly reduced damage whereas red fox (Vulpes vulpes) components did not. Alternative foods composed of Korean pine $(P$. koraiensis) bark mulch, soybean oil, and wax significantly reduced damage in terms of feeding attacks and complete girdling. A sound silvicultural approach to rodent pest management could include repellents in combination with alternative foods. These tactics may be enhanced through alteration of vole habitat by reduction of vegetative competition in young stands.
\end{abstract}

\section{Introduction}

As part of the Integrated Intensive Forest Management Project (Canadian International Development Agency) between Canada and the People's Republic of China, the senior author visited Langxiang Forest Bureau, Heilongjiang Province in autumn 1986. With co-workers from the Bureau, the influence of rodent pests on forest regeneration was investigated and experimental trials were conducted to help alleviate the damage problem.

The rodent pest problem in Langxiang Bureau and other parts of northeastern China involves population outbreaks of the red-backed vole Clethrionomys rufocanus (Shu et al. 1975, Shu 1985). During the fall and early winter of a peak year in populations of these voles, serious damage to young plantations of Scotch pine (Pinus sylvestris) and Korean pine ( $P$. koraiensis) is caused by feeding on bark and cambium of tree stems. This damage may result in complete girdling of the stem with consequent mortality, or in partial girdling which may retard tree growth and permit entry of wood pathogens. The problem is significant in plantation management. Other rodent species which may also attack trees include the northern red-backed vole $(C$. rutilus) and the reed vole (Microtus fortis).

\footnotetext{
'Department of Forest Sciences, University of British Columbia, Vancouver, British Columbia, V6T 1W5.

${ }^{2}$ Langxiang Forest Bureau, Heilongjiang Province, People's Republic of China.
}

\section{Résumé}

Cet exposé fait état de l'influence des rongeurs nuisibles sur la régénération forestière du nord-est de la Chine et des méthodes, autres que l'utilisation de répulsifs toxiques, de réduction des dommages aux arbres découlant de l'alimentation du campagnol à dos roux (Clethrionomys rufocanus). Les études ont été réalisées dans des plantations de 7 à 8 ans de pin sylvestre (Pinus sylvestris) situées à la Ferme forestière de NonGou, soit à $15 \mathrm{~km}$ au sud-est de Langxiang, Province de Heilongjiang. L'analyse des tiges révèle que la croissance radiale a été réduite de $27.5 \%$, et la croissance en hauteur de $30.5 \%$ chez les arbres endommagés (en deça du niveau létal) par comparaison avec les arbres non-endommagés. Des répulsifs synthétiques rappellant l'odeur de prédateur, fabriqués à partir des sécrétions des des glandes anales de la belette (Mustela erminea) ont significativement réduit les dommages alors que les composés de renard roux (Vulpes vulpes) n'ont pas été efficaces. Une autre source de nourriture composée de paillis d'écorce de pin de Corée ( $P$. koraiensis), d'huile de soya et de cire a permis de réduire de façon significative les dommages en terme de dégats d'alimentation et par l'annelage complet. Une approche logique pour le contrôle des rongeurs nuisibles pourrait comprendre l'utilisation de répulsifs en combinaison d'autres sources d'alimentation. Ces tactiques peuvent être améliorées par la modification de l'habitat du campagnol en réduisant la compétition herbacée dans les jeunes peuplements.
The impact of complete girdling (mortality) on the density and stocking of trees in a plantation can be assessed easily. Partial girdling, however, is an unknown element since it may be detrimental to future growth and yield of a given tree. Stem analysis can estimate the impact of partial removal of bark and vascular tissues on radial and height growth of damaged trees.

The de-barking of young trees by red-backed voles in China is similar to that recorded for peak populations of the genus Microtus (Cayford and Haig 1961, Buckner 1972, Green 1978, Sullivan and Martin 1991) in Canada. In North America, vole populations tend to fluctuate on a 2-5 year cycle in northern latitudes (Krebs and Myers 1974). The red-backed vole in northeastern China appears to have a 2-3 year fluctuation in abundance (Shu $e t$ al. 1975).

Toxicants are currently used for controlling vole populations in China, but other techniques are desired because of impacts on non-target species and the generally poor efficacy of toxicants in reducing vole populations and tree damage (e.g., Sullivan 1986).

This paper reports (1) a preliminary assessment of the influence of sub-lethal damage on tree growth, and (2) assessment of the use of synthetic predator odour repellents and alternative foods to reduce tree damage by red-backed voles in plantations of Scotch pine. 


\section{Materials and Methods}

\section{Study area}

This study was located on NanGou Forest Farm, $15 \mathrm{~km}$ southeast of Langxiang $\left(46^{\circ} 56^{\prime} 45^{\prime \prime} \mathrm{N} 128^{\circ} 53^{\prime} 30^{\prime \prime} \mathrm{W}\right)$, Heilongjiang Province. The climate is Dwa (Köppen) with hot summers and cool dry winters (Burger and Zhao 1988). The characteristic forest is composed of $P$. koraiensis (up to $50 \%$ of stand volume) mixed with valuable tolerant hardwoods such as Tilia amurensis, Betula costata, Fraxinus mandshurica, Ulmus japonica, Acer mono, Juglans mandshurica, and Phellodendron amurense; pioneer species are B. platyphylla and Populus davidiana (Burger and Zhao 1988). At higher elevations ( $>900 \mathrm{~m}$ ), boreal species such as Larix gmelini, Abies nephrolepis, Picea jezoensis and Picea koraiensis occur.

The specific study sites (compartments) at NanGou Farm were logged in the late 1970s and planted with 2-year-old Scotch pine in 1980 and 1981 . Planting density ranged from 3,000 to 3,200 seedlings/ha. Compartment size ranged from 3 to 8 ha. Competition from herb and shrub species was considerable in these plantations. Perhaps the most significant factor contributing to population outbreaks of the red-backed vole was this availability of ideal habitat (grass and shrub cover) in plantations.

\section{Stem analyses}

Stem analyses of 21 undamaged and 21 damaged 8-yearold Scotch pine trees were conducted to compare growth and vigour, before and after attack. Trees were chosen that had similar diameters and heights. Damaged trees had sub-lethal wounds with an average stem circumference girdled of $31.9 \%$. Diameter meausurements at breast height (dbh) and stump height (dsh) were taken for all trees. Cross-sectional discs were cut at stump height, sanded and cleaned, and the area $\left(\mathrm{cm}^{2}\right)$ of wood before and after the last outbreak of vole feeding damage (1984-85 winter) was measured by planimeter (average of three measurements per disc). This procedure provided radial growth measurements for 1982 , 1984 , and 1986. Radial growth on an annual basis was difficult to measure in damaged stems because the growth responses around the wound produced abnormal rings. Height increments were recorded annually from 1982 to 1986.

\section{Predator odour repellents}

Anal-gland compounds from the stoat or short-tailed weasel (Mustela erminea), 2-propylthietane and 3-propyl-1,2- dithiolane, were prepared according to Crump $(1978,1980,1982)$ and mixed in a 1:1 ratio as a "weasel mix". The principal active component of fox (Vulpes vulpes) feces, 2,5-dihydro-2,4,5-trimethylthiazoline, was prepared as outlined in Sullivan et al. (1988a). The principal volatile component from red fox urine, 3-methyl-3-butenyl methyl sulfide, was prepared according to Wilson et al. (1978) and mixed with 3-propyl-1,2-dithiolane in a 1:1 ratio as a "foxweasel mix". All compounds were produced by Semiochemicals International Limited, c/o Dept. of Chemistry, University of Calgary, Calgary, Alberta, Canada, and ranged in purity from $95 \%$ to $98 \%$.

All compounds and mixtures were dispensed in 140-ul capillary tubes (75 $\mathrm{mm}$ in length). These tubes protected the
Table 1. Average values ( $\overline{\mathbf{x}})$ with $95 \%$ confidence limits (C.L.) for dbh, dsh, and height of 21 undamaged and 21 damaged trees selected for stem analysis

\begin{tabular}{lrrrrr}
\hline & \multicolumn{2}{c}{ Undamaged } & & \multicolumn{2}{c}{ Damaged } \\
\cline { 2 - 3 } \cline { 5 - 6 } & $\overline{\mathbf{x}}$ & \multicolumn{1}{c}{ C.L. } & & \multicolumn{1}{c}{$\overline{\mathbf{x}}$} & C.L. \\
\hline dbh $(\mathrm{mm})$ & 23.3 & $20.9-25.8$ & & 20.8 & $17.9-23.7$ \\
dsh $(\mathrm{mm})$ & 54.6 & $50.8-58.4$ & & 48.8 & $44.1-53.5$ \\
height $(\mathrm{cm})$ & 215.6 & $205.3-226.0$ & & 216.6 & $203.6-229.6$ \\
\hline
\end{tabular}

compounds from adverse weather conditions and maintained the respective odour around the base of trees. Approximately $30 \mathrm{mg}$ of each compound or test mixture was placed in a given capillary tube using a 1-ml microsyringe with 20-gauge needle. One capillary tube was attached by a plastic twisttie to each tree (3-5 cm from base) in a given treatment block. Empty capillary tubes were attached to trees in an identical manner in control blocks.

Within each of three plantations in NanGou Farm, four blocks of $100(10 \times 10)$ Scotch pine trees each had treatments of weasel mix, fox, or fox-weasel mix, and a control. Each of the four blocks within a plantation was separated from adjacent blocks by at least $50 \mathrm{~m}$ to prevent contamination of odours among blocks. Treatments were installed during September 27-29, 1986, and feeding damage (proportion of trees attacked and girdled) by the overwinter peak populations of red-backed voles was assessed during May 4-10, 1987. The experiment was then terminated. The height and width of each damage wound were recorded to give an approximate measurement of the amount of bark and vascular tissues removed from a given tree.

\section{Alternative foods}

Alternative food was supplied in the form of "logs" composed of finely ground Korean pine bark mixed with a 1:1 ratio of liquid wax and soybean oil or residue. The pine bark simulated the bark and tissues of plantation trees, the soybean oil acted as an attractant for voles, and the wax when hardened kept the logs together as a waterproof unit in the field (see Sullivan and Sullivan 1988). These materials were mixed together and the molten mass pressed into styrofoam cups ( $250 \mathrm{ml}$ each), allowed to harden, and then transported to the field.

Three logs were placed around each tree at $8-10 \mathrm{~cm}$ from its base (but not obstructing access by voles) in four blocks of $100(10 \times 10)$ trees each within a Scotch pine plantation. Four alternating blocks (100 trees each) acted as controls within this plantation. Logs were set out during October 6-9, 1986 , and overwinter vole damage to trees was assessed during May 4-10, 1987 in a manner identical to that for the repellent experiment.

\section{Statistical analyses}

Average values for diameter at breast height (dbh), diameter at stump height (dsh), overall height, and radial and height increments for undamaged and damaged stems were compared using $95 \%$ confidence limits. Comparisons of the number of trees attacked and girdled in control and treatment blocks for each experiment were analyzed by replicated goodness of fit tests (heterogeneity chi-square) (Sokal and Rohlf 1969, Zar 1984). Measurements of the intensity of 

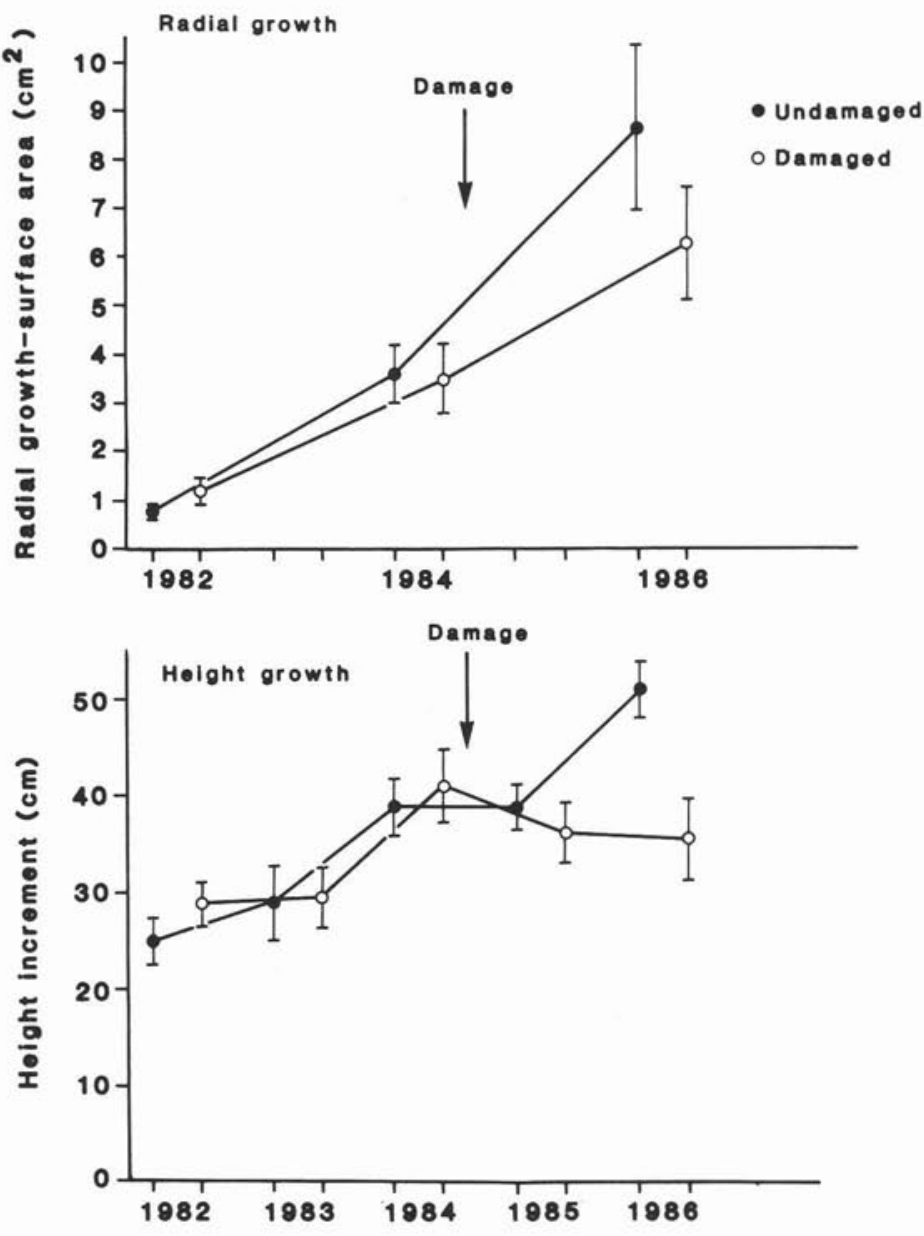

Figure 1. Comparison of average values of radial growth $\left(\mathrm{cm}^{2}\right)$ and height growth $(\mathrm{cm})$ in undamaged and damaged stems of 8-year-old Scotch pine. Vertical bars represent $95 \%$ confidence limits. Feeding damage by red-backed voles occurred during the winter of 1984-85

Table 2. Percentage of Scotch pine trees undamaged by red-backed voles in terms of feeding attacks and complete girdling. Heterogeneity chisquare (in parentheses) has been calculated for each control-treatment comparison. ${ }^{* *} p<0.01 ;{ }^{*} p<0.05$; significant difference. F-W $=$ Fox-Weasel

\begin{tabular}{|c|c|c|c|c|c|c|c|c|}
\hline \multirow{2}{*}{$\begin{array}{l}\text { Replicates } \\
\text { (sites) }\end{array}$} & \multicolumn{4}{|c|}{ Feeding Attack } & \multicolumn{4}{|c|}{ Complete Girdling } \\
\hline & Control & Weasel $\left(\chi^{2}\right)$ & Fox $\left(\chi^{2}\right)$ & $\mathbf{F}-\mathbf{W}\left(\chi^{2}\right)$ & Control & Weasel $\left(\chi^{2}\right)$ & Fox $\left(\chi^{2}\right)$ & $\mathbf{F}-\mathbf{W}\left(\chi^{2}\right)$ \\
\hline 1 & 11.2 & $14.4(0.44)$ & $15.4(0.71)$ & $17.7(1.65)$ & 17.3 & 30.0 (4.19)* $^{*}$ & $30.8(4.69)^{*}$ & $32.3(5.82)^{*}$ \\
\hline 2 & 10.2 & $62.9(58.44)^{* *}$ & $16.8(1.82)$ & $6.2(1.05)$ & 31.6 & $75.3(37.28)^{* *}$ & $34.7(0.21)$ & $9.3(14.94) * *$ \\
\hline 3 & 28.9 & $35.2(0.86)$ & $27.3(0.06)$ & $28.6(0.00)$ & 50.5 & $58.2(1.13)$ & $36.4(4.00)^{*}$ & $57.1 \quad(0.86)$ \\
\hline $\begin{array}{l}\text { Total } \\
\text { Pooled }\end{array}$ & 16.7 & $\begin{array}{r}38.1(59.74)^{* *} \\
(33.05)^{* *}\end{array}$ & $\begin{array}{r}20.0 \overline{(2.59)} \\
(1.04)\end{array}$ & $\begin{array}{r}17.5 \overline{(2.70)} \\
(0.07)\end{array}$ & 33.1 & $\begin{array}{r}55.0(42.60)^{* *} \\
(27.87)^{* *}\end{array}$ & $\begin{array}{c}34.0(8.90)^{*} \\
(0.06)\end{array}$ & $\begin{array}{c}32.9(21.62) * * \\
(0.00)\end{array}$ \\
\hline Heterogeneity & & $(26.69) * *$ & $(1.55)$ & $(2.63)$ & & $(14.73)^{* *}$ & $(8.84)^{*}$ & $(21.62)^{* *}$ \\
\hline
\end{tabular}

feeding were compared using a one-way analysis of variance. The level of significance was at least $p \leq 0.05$.

\section{Results}

\section{Stem Analyses}

Average values (with $95 \%$ confidence limits) of dbh, dsh, and height for undamaged and damaged trees were similar (Table 1). The average amount of bark and vascular tissues removed per damaged tree was $36 \mathrm{~cm}^{2}$ and the average stem circumference girdled was $31.9 \%$. Figure 1 illustrates radial and height growth of undamaged and damaged stems from 1982 to 1986 . Growth of both samples of trees was similar through 1984. After the feeding damage in the winter of $1984-85$, radial growth declined $27.5 \%$ and height growth $30.5 \%$ in damaged versus undamaged stems.

\section{Predator odour repellents}

The percentage of Scotch pine trees that were undamaged by voles showed little difference between control and the fox and fox-weasel treatments (Table 2). However, the weasel mix repellent at site 2 , and overall, did significantly reduce damage compared with the control. In terms of protection from complete girdling, all repellent treatments provided a significant reduction compared with the control at site 1 . Again, the weasel mix at site 2, and overall, resulted in significantly fewer trees girdled than in the control. However, the apparent significant results for the fox and fox-weasel overall were clearly based on heterogeneous data and should be interpreted accordingly (Table 2).

The surface area (amount) of bark and vascular tissues removed by voles may be considered as a measure of feeding 
Table 3. Average amount \pm S.E. $\left(\mathrm{cm}^{2}\right)$ of bark and vascular tissues removed from Scotch pine trees by red-backed voles

\begin{tabular}{ccccc}
\hline $\begin{array}{l}\text { Replicates } \\
\text { (sites) }\end{array}$ & Control & Weasel & Fox & F-W \\
\hline 1 & $24.6 \pm 0.8$ & $43.3 \pm 3.0$ & $44.4 \pm 3.5$ & $45.2 \pm 2.5$ \\
2 & $37.5 \pm 2.0$ & $37.2 \pm 4.4$ & $41.9 \pm 2.2$ & $60.3 \pm 3.3$ \\
3 & $42.9 \pm 2.9$ & $42.3 \pm 5.3$ & $59.4 \pm 5.8$ & $42.2 \pm 3.5$ \\
Total & $35.0 \pm 5.4$ & $40.9 \pm 1.9$ & $48.6 \pm 5.5$ & $49.2 \pm 5.6$ \\
\hline
\end{tabular}

intensity. There were no significant differences (ANOVA) in feeding intensity between control and repellent treatments (Table 3). Because of the high degree of complete girdling of trees in the majority of blocks, an assessment of sub-lethal damage (percentage of tree circumference girdled) was not possible.

\section{Alternative foods}

The percentages of Scotch pine trees that were protected from feeding attacks and complete girdling were significantly greater in treatment than control blocks (Fig. 2A). There was no difference (ANOVA) in the intensity of feeding by voles with or without the alternative food (Fig. 2B). In addition, there was little difference in the intensity of sub-lethal damage with respect to percentage of stem circumference girdled in four classes of semi-girdling (Fig. 2C). However, the bark mulch logs did significantly reduce complete girdling (100\%) damage to trees compared with those in the control blocks.

\section{Discussion}

Rodents are considered one of the major pest problems in young forests in northeast China. The intensity of the problem was clearly outlined in the assessment of overwinter damage to Scotch pine as part of our field experiments. The proportion of trees attacked averaged $>70 \%$ and those completely girdled ranged from $37 \%$ to $67 \%$. In addition, the negative impact of sub-lethal damage on tree growth must also be considered.

Despite a relatively high initial planting density (3,000-3,200 stems/ha), losses observed will seriously affect future plantation survival particularly when the major rodent pest species, the red-backed vole, reaches peak populations every 2-3 years (Shu et al. 1975). Our study area, however, represented only one forest farm in Langxiang Bureau and this degree of damage may not have been recorded in other farms and bureaus. In addition, the exotic Scotch pine appears to be more heavily attacked than the native Korean pine.

Of the repellents tested, the weasel mix provided the best protection for plantation trees, but was adequate at site 2 only. Variable snow depth and exposure to prevailing winds and low temperatures may have contributed to the poor efficacy of the weasel mix at sites 1 and 3 . Also, this was the first bioassay of predator odour compounds with voles of the genus Clethrionomys. Use of these compounds for Microtus spp. in British Columbia has significantly reduced both feeding damage and vole population levels on an experimental basis (Sullivan et al. 1988a, 1988b). Subsequent
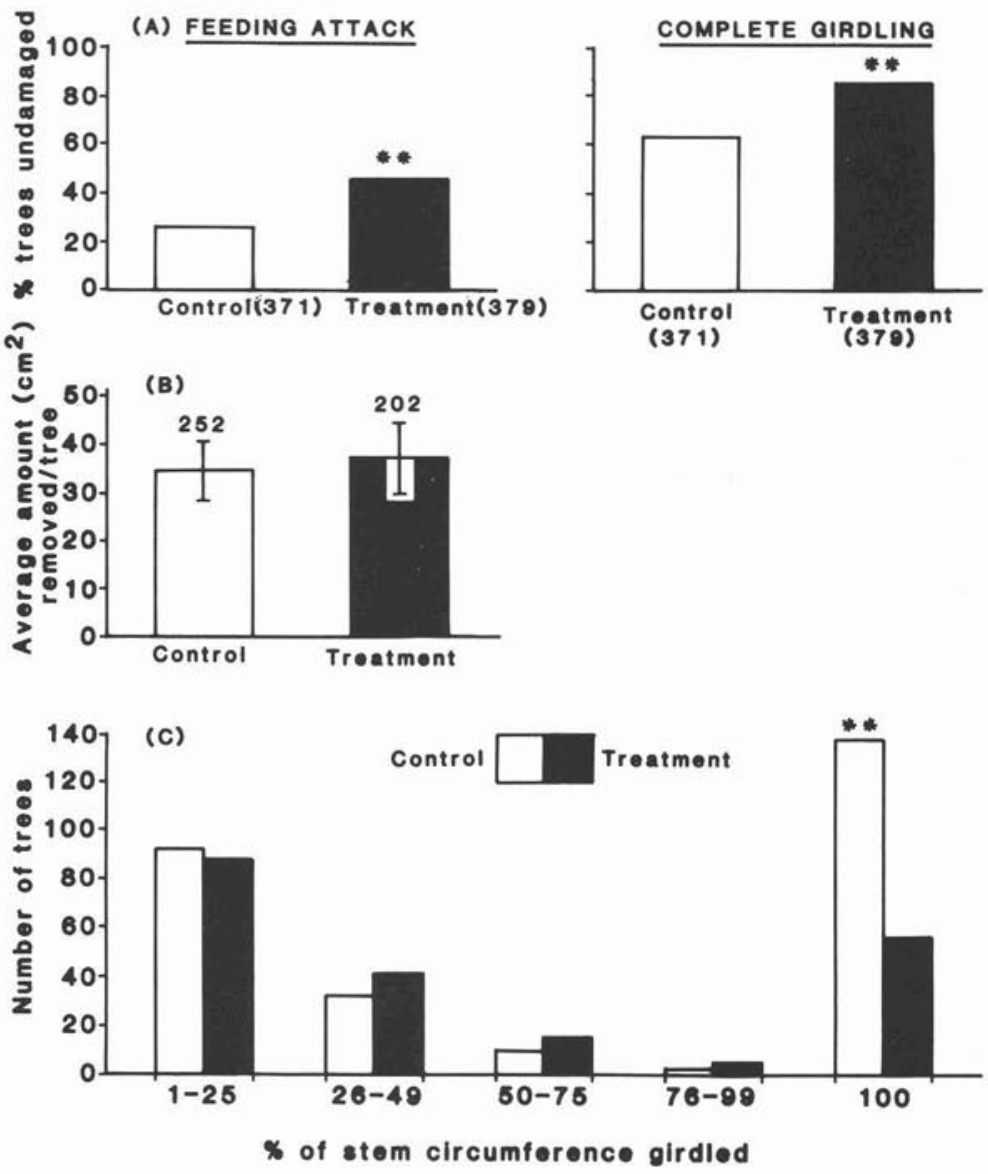

Figure 2. (A) Percentage of Scotch pine trees that were protected from feeding attacks or complete girdling by redbacked voles in control and treatment blocks on a plantation site, NanGou Farm, Langxiang Bureau. Sample size in parentheses. ${ }^{* *}, p<0.01$; significant difference by chi-square. (B) Intensity of feeding on Scotch pine trees by voles in terms of the average amount $\left(\mathrm{cm}^{2}\right)$ of bark and vascular tissues removed per damaged tree in control and treatment blocks. Vertical bars represent $95 \%$ confidence limits. Samples size is shown above upper confidence limit. (C) Number of Scotch pine trees attacked by voles in terms of a range of classes of percentage of stem circumference girdled. ${ }^{* *}, p<0.01$; significant difference by chi-square. 
work has identified two types of release devices that are significantly more effective than capillary tubes in reducing vole damage to trees (Sullivan et al. 1990).

The predators, weasel and red fox, presumably use these chemicals to mark their territories. The chemicals were originally identified and synthesized as a means of attracting these predators to a given site, and experiments indicate that they are effective in this regard (Whitten et al. 1980; Clapperton et al. . 1989). Thus, attraction of predators to these repellents would augment the biological control technique of predator introduction. This technique was recommended for the rodent pest problem in northern China by Franz and Zimmerman (1984). Chinese forest managers consider it to be a potentially viable and favourable method, environmentally, to reduce vole abundance.

We recommend that repellents in general, and the weasel anal-gland compounds in particular, be tested further in pine plantations in Langxiang Bureau. Experiments should be conducted over larger areas (several ha) in different plantation sites throughout the Bureau during the next overwinter period of feeding damage by red-backed voles. A readily applied release system is required for practical application in the field.

The use of alternative foods is a technique to reduce feeding damage to plantation trees by providing voles with a substitute food source (see Hansson 1973, Sullivan and Sullivan 1988). Voles feed on trees during fall and winter because their natural foods such as grasses and herbs are unavailable. An alternative food should be of a low-nutrient content so as not to increase survival or reproduction in the vole population, but it must be at least slightly preferred by voles to bark and vascular tissues of living plantation trees. Our experimental results indicated that a significant reduction in damage occurred when logs were made available to voles in pine plantations. Since these logs may be made economically with local materials, we strongly encourage further development of this technique in northeast China.

As with the repellent experiments, other methods of application of the logs (or other food sources) may prove more effective for operational use. Such applications could involve alternative foods placed between tree rows, in vole runways or other areas used by these animals, or some form of systematic placement of food items within and around a given plantation. In addition, the use of deciduous and coniferous branches as alternative food in young plantations should be continued (Shu, F. pers. comm.).

\section{Acknowledgements}

We thank the Canadian International Development Agency via T.M. Thomson and Associates Ltd. for financial support. Langxiang Forestry Bureau and the Forestry Experimental Centre provided logistical support. The support and assistance of Dr. John A. McLean and Mr. Hugh Marshall are much appreciated. J.A. McLean and O. Sziklai kindly reviewed an earlier draft of the manuscript. We are grateful for the field assistance of Zhou Heibin, Jin Juyao, Zhang Bao-zhong, and He Rong Chun.

\section{References}

Buckner, C.H. 1972. The strategy for controlling rodent damage to pines in the Canadian mid-west. In Proc. Fifth Vertebrate Pest Conference. Edited by R.E. Marsh. Fresno, Calif. pp. $43-48$.
Burger, D. and S. Zhao. 1988. An introductory comparison of forest ecological conditions in Northeast China and Ontario. For. Chron. 64: 105-115.

Cayford, J.H., and R.A. Haig. 1961. Mouse damage to forest plantations in southeastern Manitoba. J. For. 59: 124-125.

Clapperton, B.K., E.O. Minot, and D.R. Crump. 1989. Scent lures from the anal sac secretions of the ferret Mustela furo L. J. Chem. Ecol. 15: 291-308.

Crump, D.R. 1978. 2-Propylthietane, the major malodorous substance from the anal gland of the stoat. Tetrahedron Lett. 1978: 5233-5234.

Crump, D.R. 1980. Thietanes and dithiolanes from the anal gland of the stoat (Mustela erminea). J. Chem. Ecol. 6: 341-347.

Crump, D.R. 1982. Synthesis of (2S)-2-Propylthietane. Aust. J. Chem. 35: 1945-1948.

Franz, J.M., and G. Zimmerman. 1984. Problems of forest protection in northern China with special regard to biological control. Anzeiger fur Schaedlingskunde Pflanzenschutz Umweltschutz 57: 81-87.

Green, J.E. 1978. Techniques for the control of small mammal damage to plants: A review. Alberta Oil Sands Environ. Res. Proj., Rep. No. 38. 111 pp.

Hansson, L. 1973. Fatty substances as attractants for Microtus agrestis and other small rodents. Oikos 24: 417-421.

Krebs, C.J. and J.H. Myers. 1974. Population cycles in small mammals. Adv. Ecol. Res. 8: 267-399.

Shu, F. 1985. On the number of the large-toothed red-back voles (Clethrionomys rufocanus) on different slopes and its meaning in rodent pest prevention for young forests. Acta Theriologica Sinica 5: 263-267.

Shu, F., K. Yang, M. Guo, Y. Lui, F. Tian, and C. Li. 1975. The rodent pest in Yichun forest region and our opinions of pest forecasting. Acta Zoologica Sinica 21: 9-17.

Sokal, R.R. and F.J. Rohlf. 1969. Biometry. W.H. Freeman and Company. San Francisco. 776 p.

Sullivan, T.P. 1986. Understanding the resiliency of small mammals to population reduction: poison or population dynamics? In Control of Mammal Pests. C.G.J. Richards and T.Y. Ku. (Eds.) Taylor and Francis Ltd., London. Supplement No. 1 to Tropical Pest Management 32: 69-82.

Sullivan T.P. and W.L. Martin. 1991. Influence of site factors on incidence of vole and lemming feeding damage to forest plantations. West. J. Appl. For. (in press).

Sullivan, T.P. and D.S. Sullivan. 1988. Influence of alternative foods on vole populations and damage in apple orchards. Wildl. Soc. Bull. 16: 170-175.

Sullivan, T.P., D.R. Crump and D.S. Sullivan. 1988a. Use of predator odors as repellents to reduce feeding damage by herbivores. III. Montane and meadow voles (Microtus montanus and Microtus pennsylvanicus). J. Chem. Ecol. 14: 363-377.

Sullivan, T.P., D.S. Sullivan, D.R. Crump, H. Wieser, and E.A. Dixon. 1988b. Predator odors and their potential role in managing pest rodents and rabbits. In Proc. 13th Vertebrate Pest Conference, A.C. Crabbe (Ed.). Monterey, Calif. University of California, Davis. pp. 145-150.

Sullivan, T.P., D.R. Crump, H. Wieser, and E.A. Dixon. 1990. Comparison of release devices for stoat (Mustela erminea) semiochemicals used as montane vole (Microtus montanus) repellents. J. Chem. Ecol. 16: 951-957.

Whitten, W.K., M.C. Wilson, S.R. Wilson, J.W. Jorgenson, M. Novotny and M. Carmack. 1980. Induction of marking behaviour in wild red foxes (Vulpes vulpes L.) by synthetic urinary constituents. J. Chem. Ecol. 6: 49-55.

Wilson, S.R., M. Carmack, M. Novotny, J.W. Jorgenson, and W.K. Whitten. 1978. Isopentenyl methyl sulfide. A new terpenoid in the scent mark of the red fox (Vulpes vulpes). J. Org. Chem. 43: 4675-4676.

Zar, J.H. 1984. Biostatistical Analysis. 2nd ed. Prentice-Hall, Inc. New Jersey. 718 p. 